Article

\title{
Explanatory Factors of Entrepreneurship in Food and Beverage Clusters in Spain
}

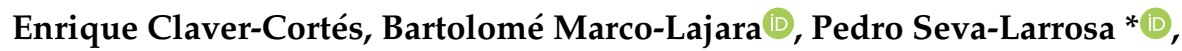 \\ Lorena Ruiz-Fernández and Eduardo Sánchez-García $\mathbb{D}$ \\ Department of Business management, University of Alicante, 03690 Alicante, Spain; \\ enrique.claver@ua.es (E.C.-C.); bartolome.marco@ua.es (B.M.-L.); lorena.fernandez@ua.es (L.R.-F.); \\ eduardo.sanchez@ua.es (E.S.-G.) \\ * Correspondence: pedro.seva@ua.es
}

Received: 27 May 2020; Accepted: 9 July 2020; Published: 13 July 2020

check for updates

\begin{abstract}
Research into entrepreneurship has gradually changed its perspective over recent decades, becoming a very relevant research topic. In the last few years, various lines of research have been developed to find new explanatory factors of entrepreneurial propensity in specific socioeconomic and institutional contexts, among which we can highlight local territorial agglomerations. The main objective of the study is to offer new knowledge about the factors that influence the entrepreneurial capacity of food and beverage clusters using different secondary sources. To reach this objective, we analyze how the degree of agglomeration, institutional thickness, and knowledge affects new companies created in the last five years within the 37 food and beverage clusters in Spain. Multiple regression results show that company agglomeration and the presence of supporting institutions positively influence entrepreneurial capacity in these clusters. However, available knowledge has a negative influence on entrepreneurial capacity in these specialized environments.
\end{abstract}

Keywords: entrepreneurship; clusters; food beverage; agglomeration; institutions; knowledge

\section{Introduction}

This work links some of the most important aspects in business management and regional science, such as entrepreneurship, institutions, and knowledge developed in highly specialized productive contexts such as industrial districts or clusters. Throughout history, entrepreneurship has played an essential role in economic development at different levels (national, regional, and local), both in advanced and developing economies [1]. This is essentially because companies are a source of wealth, employment, resources, and innovation [2,3]. Regarding the above, we can highlight the importance of the determinants of the differences between regions in terms of new firm formation rates [4]. Apart from entrepreneurs, institutions are essential for the generation of environments conducive to entrepreneurship [5], while knowledge is an essential factor and the most important strategic resource that companies have [6-8].

Recently, the relationship between entrepreneurship and economic growth has acquired particular relevance in both the academic and policy scene [9]. The growth of economic output implies an increase in regional demand and a rise in the general level of entrepreneurial opportunities. Thus, the level of regional economic development is often argued to have a large influence on the rate of entrepreneurship [10,11].

According to [12], the classical definitions of entrepreneurship can be broadly categorized into the behavioral view and the occupational view. The behavioral view stresses the innovative and risk-taking spirit of entrepreneurs. According to this view, entrepreneurial behavior usually entails the creation of new organizations [13]. The occupational view defines an entrepreneur as someone 
who works for his/her own account and risk [14], distinguishing between wage employment and self-employment. In this paper, the concept "entrepreneurship" refers to new firm formation.

Different factors have been used to explain the rate of new firm formation in regions $[4,15,16]$. We focus on agglomeration economies to explain differences in cluster entrepreneurship. According to [12], recent theoretical development conceptualizes entrepreneurship as a critical element in the genesis and development of industrial clusters.

Entrepreneurship is commonly held to be enhanced in regions with strong clusters [17]. However, the relationship between clusters and entrepreneurship has a double perspective in the existing literature. On the one hand, there is the view of entrepreneurship as a consequence of industrial concentration [18-20], on the other hand, as a cause of cluster formation [12].

From the consequence point of view, new entrepreneurial firms are attracted to clusters by the pool of skilled and specially trained personnel; access to risk capital; favorable demand conditions; reduced transaction costs; and motivational factors, such as prestige and priorities [21-23]. Authors such as Marshall and Porter conceived entrepreneurship and industrial clustering as tightly interwoven dynamic processes. Porter holds that "The formation of new businesses within a cluster is part of a positive feedback loop", and sees the cluster in the role of an incubator of entrepreneurship. From the cause point of view, authors such as [24] conclude that "entrepreneurs spark cluster formation and regional competitive advantage". Thus, agglomerative economies that benefit entrepreneurship are also identified as drivers of cluster development.

Despite this background, little research has been done on the effect of localization economies on entrepreneurship. The current empirical literature on industrial clusters mainly focuses on externalities that improve productivity, international competitiveness, and innovation [25], but the effects of externalities generated by clusters on new firm creation are largely unexplored. Notwithstanding the efforts undertaken by researchers to explain the relation between clusters and new firm formation $[24,26,27]$, there is no systematic examination of their internal mechanisms, or any empirical evidence. The analysis of the factors that determine variations in the formation of companies in clusters is therefore critical to understand the entrepreneurship differences in these business environments, as well as a more general understanding of the determinants of entrepreneurship.

In order to contribute to this line of research, this work has two main objectives: (1) to offer new knowledge about the factors that influence the entrepreneurial capacity of the food and beverage clusters, and (2) to analyze the differences in the entrepreneurial capacity of these clusters in Spain. This study is the first to test the differences in the levels of entrepreneurship of food and beverage clusters in Spain. As such, it contributes to the empirical literature on the role of agglomeration, institutions, and knowledge of on entrepreneurship in clusters. We have focused on the food and beverage industry because it is the largest industrial sector in Spain in terms of turnover (113,593 million euros), gross value added (2.5\% of GDP), gross domestic product (15.5\% of GDP), and job creation (around $18 \%$ of the total of the Spanish manufacturing sector) [28]; besides, it is traditionally characterized by companies in clusters. Moreover, according to the systematic literature review on agglomeration, clusters, and industrial districts performed by [29], the food industry has traditionally hardly been analyzed under any of these theoretical frameworks. In fact, according to some authors [30], it is necessary to analyze the effect of agglomeration not only in sectors related to high technologies, but in the traditional ones. However, the results offered by [29] indicate that in recent years (from 1998 to 2015) scientific production in this area has experienced an increase of $94.8 \%$, which is not surprising, given that it is an industry that has traditionally developed around clusters and industrial districts due to its strong territorial roots. For example, in the case of Spain and the food and beverage industry, some clusters own certificates of designation of origin, which act as quality assurance and play a key role as a differentiating factor. Those companies located within a cluster that implements the established production and processing standards are able to use them. In addition, it is necessary to analyze the agglomeration of firms belonging to different industries, even among traditional industries. In fact, [31] 
determined that in the food industry agglomeration has greater effects on firms' performance than other traditional industries, such as mining or textile.

The work is structured as follows. After this brief introduction, the second section offers a review of the literature on the factors that influence entrepreneurship in industrial clusters and presents the hypotheses of the paper. The third section covers the methodology carried out in the empirical analysis, specifying the sample, the measurement of variables, and the analysis technique used. In Section 4 , the main results of the work are presented, both descriptive and those derived from the multiple regression model. Finally, in Section 5 the main conclusions are presented, as well as limitations and future lines of research.

\section{Literature Review}

\subsection{Agglomeration and Entrepreneurship in Clusters}

Entrepreneurship is often considered as a human feature, a result of an individual's capability to recognize and exploit opportunities for profitable production of goods or services [32]. However, the regional socioeconomic environment plays a key role as a driver of entrepreneurial activity [33], and it is fundamentally a regional phenomenon [34,35]. Over the years, academics in the field of regional economics have carried out different studies in order to analyze the role of agglomeration economies in the regional rates of new firm formation [36,37]. In fact, a wide range of current studies suggest that localization economies have positive effects on entrepreneurship [27,36,38-40]. However, there are few empirical studies that consider this in the particular context of the cluster or industrial district [41].

In our opinion, we can distinguish three processes by which clusters can positively influence the creation of new companies:

\subsubsection{Clusters Favor the Detection of New Business Opportunities}

The dynamic nature and turbulence of today's competitive environments results in a continuous flow of new challenges and opportunities. This situation can be taken advantage of by entrepreneurs who have the vision and the appropriate knowledge of the socio-economic context by identifying and exploiting the potential opportunities of the environment [42]. Furthermore, localization economies could favor the degree of specialization of the regional labor market and suppliers, which is defined as the "thickening effect" [40,43]. Within a cluster, the agglomeration of competencies, technologies, and actors, as well as the existence of local social networks, foster the generation and seizure of opportunities by both established and new companies [44]. Several empirical studies in this area confirm the existence of differences in regional entrepreneurship rates, which could be due to the existence of dissimilar types and the amounts of regional opportunities for new firm formation [4].

The competitive-cooperative environment is a characteristic element of clusters which facilitates the detection and exploitation of business opportunities and, therefore, fosters entrepreneurship and specialization in terms of techniques, processes, and knowledge, both of the main industry and of a whole series of complementary and auxiliary activities $[26,45]$. In this way, the emergence and development of relational networks within clusters is encouraged and the climate of competition and cooperation generated stimulates the competitiveness and efficiency of the participating companies [46].

Accordingly, opportunities can be created and seized by the cluster's actors on the basis of the existing ways of doing things [47]. Entrepreneurs, as long as they take part in the cluster, are able to take advantage of these opportunities. The spillover theory of entrepreneurship developed in the past couple of decades has drawn a lot of attention from academics as an explanation of how regional knowledge is able to influence the level of regional entrepreneurship [48]. Building on this theory, the investment of resources in new knowledge creation generated endogenously by companies favors technological progress and the dissemination of knowledge, while making it easier for entrepreneurs to 
identify and exploit new opportunities [49,50]. In addition, the use by entrepreneurs of under-exploited knowledge generated by third parties allows them to generate new economic opportunities [51].

The specialization of a cluster derives from the segmentation of the productive process, exerting upward pressure on the competitiveness of companies [52]. As a result, smaller firms may in many cases choose to specialize in one phase of the value chain, which allows them to survive and, in most cases, achieve success. To this end, they rely on a number of reliable and geographically close specialized supply companies (almost as a laboratory tool) in addition to a whole range of support agencies and institutions, which fosters a dynamic of continuous experimentation and encourages the development of technological innovations [53]. According to Reference [54], new entrepreneurial projects face less risk of failure in regions with a higher degree of productive specialization. The existence of linked specialized firms related to a main industry and other specialized factors in the context of a cluster generate the appropriate conditions for entrepreneurship, such as knowledge spillovers and complementarities regarding capacities, technologies, customer needs, and marketing, among others [55]. Knowledge spillovers are defined by [51] as "the external benefits from the creation of knowledge that accrue to parties other than the creator, occur at multiple levels of analysis, be it within or across organizations and networks".

According to Reference [56], productive specialization is one of the main externalities generated in the context of an industrial cluster. References [57] and [58] analyzed some Italian clusters related to the food and beverage industry and found that firms belonging to the clusters show a greater efficiency in technical and productive issues than those geographically dispersed, and an enhanced product quality. The fact that technology facilitates the division of the productive process into different phases allows the logic of the cluster to reveal the way in which companies specialize in one or several stages of the process, developing a specialized knowledge in the phase of the process undertaken [59]. Furthermore, companies have access to specialized suppliers and distributors located geographically close, as well as higher demand [60]. Consequently, the division of production into stages, each carried out by different companies, usually leads to a gradual increase in the levels of professionalism and specialization as a result of the continuous development of new, more efficient and effective techniques, which supposes an opportunity for new incoming companies when there is increased demand [61]. Thus, the productive specialization of clusters allows for increased opportunities for learning, innovation, and entrepreneurship [62].

\subsubsection{Clusters Facilitate Access to Specialized Knowledge}

From a geographical perspective, clusters generate more specialized knowledge in their main industries than in other non-specialized areas, particularly tacit knowledge [63], and it is efficiently spread locally [64]. Furthermore, the mobility of human capital between firms fosters knowledge sharing within the cluster [65]. From this angle, we could consider industrial clusters as local specialized knowledge pools [66] from which entrepreneurs can learn and profit. In addition, geographical proximity favors the transfer of knowledge, particularly tacit, inasmuch as it increases the chance of direct contact $[67,68]$.

According to Reference [37], when they locate their activities in a cluster, nascent entrepreneurs often have rich experience in existing local firms, which constitutes important prior knowledge to help explore new market opportunities. Clusters are industrial agglomerations whose members are embedded in networks, which are composed of formal and informal relationships and are a key element for regional entrepreneurship $[23,27]$. The interaction and exchange of tacit knowledge by specialists fosters knowledge spillovers [69]. In the same vein, geographical proximity allows continuous interaction among individuals specialized in a specific activity of the production process, which favors mutual learning as occurs, for instance, between local wine producers belonging to the Colline Novaresi wine cluster [70]. Thus, clustered firms related to a main industry are more innovative, and new knowledge is disseminated rapidly through the effects of proximity, specialized human resources, and cooperation between various actors [21,71]. Accordingly, nascent entrepreneurs have 
access to resources and knowledge easier and faster than in an isolated environment [37]. Furthermore, the special resource endowment of clusters lowers entry-exit barriers to entrepreneurs, reduces their risk, facilitates the transmission of codified or tacit knowledge, and fosters innovation [12].

The geographical and cognitive proximity found in a cluster positively influences the degree of interaction, cooperation, and trust between its specialized members, as well as the establishment of social networks and knowledge spillovers [72-74]. Furthermore, it could reduce the costs of creating and maintaining an adequate amount and intensity of social interactions [75]. The agglomeration of firms favors knowledge spillovers [76,77]. With regard to this, [78] developed the concept of "Buzz", which they defined as "the information and communication ecology created by face-to-face contacts, co-presence and co-location of people and firms within the same industry and place or region". These authors determined that agents in a cluster are able to participate in its "buzz" without investing a considerable amount of resources, although the sort of buzz they receive depends on their behavior, network of ties, and interaction records.

As entities made up of several agents in a main industry, clusters have a dynamic nature, and their development relies on who their members are, how many they are, how they behave internally and externally, and on other features related to knowledge and networks $[79,80]$. In the context of a cluster, mutual trust and engagement are developed by cooperation, whereby agents share experiences and try to solve the same types of problems related to the main industry and certain kinds of technologies [78]. They also usually share some characteristics such as language, relationships, knowledge about the members of the cluster, and attitudes, among others [81]. These characteristics form a unique environment, within which the members of the cluster have access to specialized local knowledge, the local learning processes fostered by the existence of social networks, and high levels of interaction and cooperation [82].

\subsubsection{Clusters Attract Companies from Other Locations}

From an international perspective, in recent years the literature has highlighted the importance of agglomerations and especially the role played by industrial districts or clusters in attracting international companies [83]. Networks of companies with related activities sway the location decision of multinational companies, both between different countries and within them [84-87]. This emerging approach poses a new challenge to industrial districts and clusters-that of attracting new companies that provide these environments with greater competitiveness at the international level, favored, in part, by the incorporation of new knowledge and skills from abroad. The benefits package derived from the economies of agglomeration becomes greater with the increase in companies related to a main industry located geographically close [88], and normally means better access to specialized inputs, human capital, and knowledge [89]. These advantages allow clustered firms to improve their performance [90].

Most entrepreneurs locate their new businesses in their home region due to the fact that, among other reasons, business opportunities are local rather than universal [91]. Thus, we could say that proximity increases the chances of finding entrepreneurial opportunities. In addition, knowledge spillovers and other types of agglomeration economies related to a main industry influence the location decisions of multinational firms with similar activities that are looking for knowledge creation [92]. Entrepreneurs that locate their activities in a cluster can more easily assemble the specialized material and intangible resources necessary for the exercise of their business activity, and detect and profit from existing or new opportunities. Furthermore, a local environment provides multinational subsidiaries a major source of knowledge to carry out their innovation processes, fosters their capacity for new knowledge creation, and generates other specific advantages [93,94]. Some of the advantages identified by $[95,96]$ related to the agglomeration of firms belonging to the food industry are access to specialized assets and services and joint efforts in various activities, such as R\&D and advertisement. According to Reference [97], the agglomeration of similar firms fosters innovation amidst foreign enterprises. 
Tacit knowledge is embedded in firms, in their routines, human capital, and communication patterns, among others, and explains why it is an aggregation procedure [98]. Innovation, due to its strong connection with tacit knowledge, could be considered a local process [69,99]. Accordingly, firms with greater knowledge stocks obtain higher benefits from agglomeration [88]. Thus, foreign companies are able to benefit from positive externalities and spillovers derived from their location in an agglomeration composed of local firms embedded in networks and related to a main industry [100].

According to Reference [101], clusters are formed by a set of inter-organizational networks in which members are related and interact with each other. Within clusters, the existence of social ties and a large degree of interaction favor knowledge exchange, inter-organizational learning, and a reduction in transaction costs and foster network building and flexible specialization [102,103]. The interaction carried out within these networks favors the generation of trust, which is necessary for the efficient development of activity by the different companies in the productive system. Likewise, it positively influences the coordination of activities, the compatibility of the technologies used by companies, and their development and continuous adaptation, thus establishing the bases of agreements and long-term relations, attracting geographically dispersed companies and promoting entrepreneurship [104]. Furthermore, location is usually a fundamental aspect in the food and beverage industry because of the local natural resources, such as the case of the fruit and vegetable industries of the region of Romagna and Salermo [57], California and its wine industry [105], or Modena and its pork industry [106]. Thus, positive externalities developed within a cluster could make it desirable for other firms, especially multinational corporations, to locate their subsidiaries there. According to this, clusters are able to receive foreign direct investment and increase the flow of knowledge spillovers from and to large multinational corporations $[93,107]$.

Consequently, we could think that the greater specialization and internal division of work in the district favors the emergence of new opportunities for entrepreneurship. Moreover, these opportunities are more likely to arise among people who directly or indirectly have a relationship with the activity carried out in the district itself. Thus, the following hypothesis is put forward:

Hypothesis 1 (H1). Agglomeration is positively related to entrepreneurship in food and beverage clusters.

\subsection{Institutional Thickness and Entrepreneurship in Clusters}

Research on entrepreneurship has gradually changed its perspective in recent decades, moving from being based essentially on the psychological characteristics of the entrepreneur to taking into account other relevant elements of the socio-economic and institutional context [108-110]. Thus, especially in recent years, the characteristics of the environment have acquired great importance in explaining the differences in the entrepreneurial propensity of country, region, and/or local territorial agglomerations [26,56,111-113].

The comparative advantage between geographical locations and foreign investors' choices are influenced by the institutional context, as it affects the type of resources and capabilities that foreign enterprises need to obtain and improves their legitimacy and curbs transaction costs $[114,115]$. Thus, to invest, foreign firms must choose, besides the country, the specific location within it [116]. According to this, within clusters institutions moderate the connection between the geographical agglomeration of firms related to a main industry and the economic results of foreign enterprises [100].

The institutional context, especially that of an informal nature, plays an essential role as a driver of entrepreneurship $[5,117]$ and can have a significant influence on the achievement of the development objectives established by companies, especially in newly created ones [118], as well as on the capacity of entrepreneurs to perceive opportunities, their attitude towards risk, and strategic decision-making [119]. Therefore, the analysis of the institutional context allows for an understanding of the fundamental factors affecting business creation.

Several studies suggest that institutional thickness fosters regional socioeconomic development [120-122]. The concept of "institutional thickness" alludes to a well-connected and 
integrated network formed by different organizations and institutions that support the surrounding firms, local or regional [123], and it is important not only to have such institutions but also to have the synergies of interaction, collective representation, and a common purpose among the actors involved [121]. These institutions participate in the generation and dissemination of information and knowledge and promote the development of cooperation projects [124]. According to this, local development policies have been focused on the development of synergies among regional agents [114].

Thus, in some regions, the interaction and interrelationship between universities, scientific laboratories, technological institutes, and chambers of commerce, among others, and the productive fabric has been stimulated, with the aim of improving the innovation, marketing, management, and training processes in companies [125]. In the context of the cluster, the basic function of these institutions (local and regional) is to offer support to companies in the local industry in very diverse aspects such as specialized training, information, technical issues, and research [126]. Therefore, the institutions cover important functions related to cooperation, advice, training, and mediation between different companies and between companies and other bodies, both within and outside the cluster. They also act as monitors of the strategic process, which fosters the development of a common strategy and the improvement of the joint operation of the group of firms belonging to the cluster [127].

Accordingly, institutions are an important component of the networks that make up the social capital of the cluster [127], since they foster trust, favor cohesion between agents, stimulate entrepreneurship, and facilitate the incorporation of companies in the district [123]. In this line of argument, Reference [37] state that links between related firms, institutions, and other agents could play a key role as determinants of entrepreneurship. We regard the food and beverage industry generally builds its prestige on local factors, specialized institutional regional frameworks and sources of know-how, which are difficult to replicate in other territories [57]. However, the characteristics of the institutional structure can influence the generation of different patterns of entrepreneurship, in particular business environments [108]. Therefore, we believe that the degree of development of the institutional environment surrounding the cluster will determine the opportunities or limitations for entrepreneurship. Thus, clusters characterized by a high institutional thickness will be more favorable for entrepreneurship, while those with a low institutional thickness will be less prone to entrepreneurship. Based on the above, the following hypothesis is put forward:

Hypothesis 2 (H2). Institutional thickness is positively related to entrepreneurship in food and beverage clusters.

\subsection{Knowledge and Entrepreneurship in Clusters}

A theoretical development in economics sheds new light on knowledge as a driving force for economic growth [128-131]. In the field of business, knowledge has acquired fundamental relevance for companies, representing one of their main sources of competitive advantage [45]. When speaking of knowledge, we can distinguish an ontological dimension, which refers to the area in which it is generated (individual, group, organizational, and/or inter-organizational) and an epistemological dimension, which refers to its explicit or tacit nature [132].

Knowledge and innovation intensity as explanatory factors of entrepreneurship have experienced an increase in relevance in recent years and have been tested by several studies within the framework of the knowledge spillover theory of entrepreneurship and its regional dimension [15,133]. This theory emphasizes the role of R\&D activities carried out by firms and research organizations on regional knowledge spillovers, which could favor the existence of entrepreneurial opportunities. Thus, regions with a large amount of knowledge spillovers might have higher rates of entrepreneurship.

The knowledge spillover model of entrepreneurship considers entrepreneurship as a process of identifying business opportunities by tapping into unutilized knowledge by incumbent firms [49]. In this sense, a noticeable recent development in the entrepreneurship literature is a heightened interest in the role of knowledge in the new firm formation process. 
An interesting aspect of the nature of knowledge is the importance of its spatial dimension. Each territory has certain socio-economic characteristics, resulting in the existence of knowledge environments specific to each geographical area, some of which represent a relative advantage for companies located in the territory [134]. A large number of studies have found that knowledge spillovers are often geographically localized [135-138]. This means that entrepreneurship is likely to be, by nature, a local phenomenon. Accordingly, the rate of firm birth can hinge upon the distribution and nature of local knowledge [133,139].

In this sense, geographical proximity encourages the creation of links between the different agents located in a cluster [140], because it generates the opportunity to establish close interactions and thus favors the generation of inter-agent trust [69] and, consequently, the effectiveness of local learning [141]. These characteristics could foster the generation and development of collective learning environments. According to Reference [142], the local knowledge base and the dissemination of knowledge in the context of a cluster are potential sources of opportunities for the generation of innovations and entrepreneurship.

In general terms, companies can acquire knowledge from both internal and external sources [143]. Internal sources refer to the actions that the company itself takes to improve its knowledge base. As for external sources, a distinction can be made between knowledge from other companies in the industry (direct competitors or not) and codified knowledge. Furthermore, training represents an important part of the latter source of knowledge. However, many enterprises, especially small ones, given their limited investment in $R \& D$, are not able to internally generate all the knowledge necessary to achieve high competitiveness rates.

More than three decades ago, several authors showed evidence for a positive effect of the degree of specialization of workers on the generation of positive externalities and economic growth $[140,144]$. A good example of this could be the firms belonging to the clusters of ham industry located in the "Emilia-Romagna" area, which workers have proved to be clearly more productive than those belonging to other geographically dispersed companies [57] In addition, inasmuch as it encompasses a full set of knowledge and skills, which are necessary to detect and tap into new opportunities, human capital plays an essential role in entrepreneurship [9]. According to Reference [145], there is a shortage of employee talent in the food industry in Spain, affecting $46 \%$ of companies. However, aware of the importance of employee qualifications for business success, companies have increased their demand for qualified personnel, especially in the technical and research categories, which account for around $14.4 \%$ of the total. In this regard, this research work focuses on the knowledge acquired through specialized training in a region, as it is considered a determining factor for the performance of entrepreneurs, especially in the detection and exploitation of new business opportunities.

Accordingly, the presence of a set of different kinds of educational and research institutions directly affects the existence of specialized human capital in the main industry of the cluster, as well as the building and dissemination of knowledge, both directly and indirectly [146]. Universities and professional training centers generate a great part of these positive externalities $[147,148]$. Thus, although these types of institutions are external to companies, they belong to the cluster's inter-organizational sphere. Their activities are particularly relevant to the generation and dissemination of explicit knowledge.

Vocational training centers carry out an essential training task when it comes to providing companies with qualified professionals in sufficient quantity and quality by teaching the appropriate subjects according to the type of profiles demanded by the organizations. According to Reference [149], in companies where specialized employees with professional training are allowed to contribute ideas, interesting and valuable feedback is obtained, which allows them to improve their products and/or processes.

With respect to universities, they provide companies with adequately trained and skilled personnel to perform tasks at different levels of the organizational structure [150]. In addition, they provide specialized services in many different areas of scientific and technological knowledge, collaborate 
with companies in certain areas of research and development, and make available a series of patented technologies through the acquisition of their corresponding patents [151,152]. University investment in research and development positively affects new firm creation, which in turn fosters employment and economic growth [153]. Furthermore, in accordance with [135], it is highly and positively correlated with local innovative activity.

Therefore, it is possible to deduce the relevance and impact of universities on the adequate performance of local established and new companies, since they benefit from the aforementioned positive externalities generated by this type of institution. According to Reference [57], the success of local food industries depends, to a large extent, on the existence of specialized institutions, know-how, and support infrastructures. Thus, it is necessary to enhance the potential of the existing clusters and their competitiveness, by creating and improving a specialized institutional framework which supports the surrounding clustered firms [60], particularly providing educational programs specialized in the main industry $[154,155]$.

Reference [43] analyzed the underlying factors of new firm formation using the Longitudinal Establishment and Enterprise Microdata (LEEM) and found evidence to support the hypothesis posed by [16]. They conclude that the presence of college graduates in labor market areas (LMA) favors new firm formation, as opposed to LMAs with a high percentage of less skilled workers. Thus, they suggested a positive correlation between the new firm formation rate and the "size" of a region's knowledge base. In light of the above discussion, it could be considered that the positive externalities generated by a greater training supply located in the industrial districts could favor entrepreneurship. Thus, we propose the following hypothesis:

Hypothesis 3 (H3). Knowledge is positively related to entrepreneurship in food and beverage clusters.

Next, we will graphically present the relationships proposed in the hypotheses to facilitate their comprehension (Figure 1).

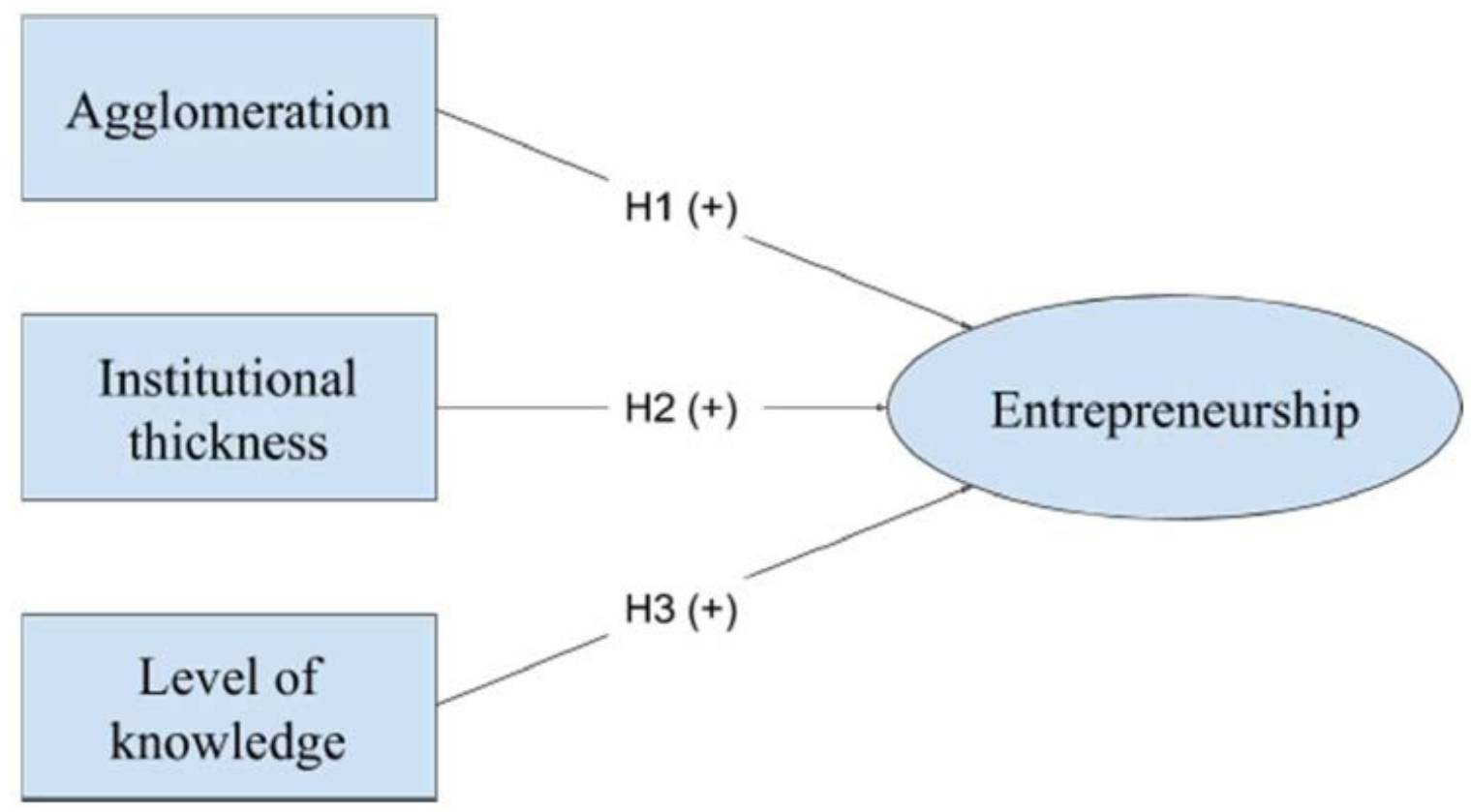

Figure 1. Theoretical model of the factors that influence entrepreneurship in clusters. 


\section{Methodology}

\subsection{Population and Sample}

The research population is made up of Spanish food industry clusters. In Spain, the food and beverage sector is the biggest industrial sector and comprises a total of 31,342 enterprises $(17.4 \%$ of the whole manufacturing industry). Specifically, it includes around $20.5 \%$ of net product sales, $18.3 \%$ of employment, $18.0 \%$ of gross investment in material assets, and $15.5 \%$ of the Spanish industrial sector's added value, according to the latest Industrial Firm Survey [156].

The sample is composed of 37 food and beverage clusters located in Spain, of which 30 are specialized in the food industry and 7 in the production of beverages (see Appendix A). According to Reference [157], the food and beverage industry has the third highest number of clusters in Spain, as opposed to 7 in Italy [158] and 7 in the UK [159].

\subsection{Data Collection and Variables Measurement}

The food and beverage industry clusters have been identified according to the Local Labor Systems' (LLSs) proposal of [157], who identified 806 LLSs across different economic activities in Spain. Therefore, our task consisted of checking which of the food industry LLSs were still operative, using the employment and population data for 2017. This led us to identify 437 municipalities in the country, pertaining to 37 LLSs that meet the conditions to be considered as industrial districts/clusters.

The data used to test the hypotheses come mainly from secondary data sources, and we can highlight the following: the SABI database (Sistema de Análisis de Balances Ibéricos) for data on new firm creation; the Camerdata database to calculate the degree of company agglomeration; and for data on institutions and knowledge, we have used various external sources (the Universia database; the web page of the Ministry of Agriculture, Fishing, and Food; The National Registry of Associations; among others). We will now describe how we measured the variables used in the analysis.

\subsubsection{Dependent Variable}

ENTREPRENEURSHIP IN A CLUSTER. Various measures of entrepreneurship have been used in the literature. Many researchers focus on the number of startups or the rate of startups to measure entrepreneurship [27,56]. In this study, entrepreneurship (ENTR) is measured through a coefficient of the number of companies created in each cluster in a five-year period (2013-2017), relativized by the total population of each cluster.

\subsubsection{Independent Variables}

INSTITUTIONS IN A CLUSTER (INST). The variable institutions measures the presence of institutions in a territory (province). It is measured through a coefficient calculated by the number of institutions that support the food industry in each province, divided by the number of food industry companies in the same province. The institutions used to calculate this index are: technology centers, research institutes, universities, professional training centers, business associations, and food industry inter-professional organizations.

KNOWLEDGE IN A CLUSTER (KNOW). The variable knowledge measures the food industry training supply provided by universities and professional training centers in a territory (province). It is calculated through an index that uses the number of places offered on each university course (degree, master's, and $\mathrm{PhD}$ ) per province and the number of places offered on vocational training courses (basic, medium, and superior) per province, relativized by the number of inhabitants.

AGGLOMERATION IN A CLUSTER (AGGL). The variable agglomeration measures the degree of productive specialization in each food and beverage cluster. The geographical concentration of firms has been measured by different ways in the agglomeration literature. Some studies use the density of establishments in each specific geographical area [30,60,95], while others use employment in a certain industry and geographical area $[160,161]$. In this study, we use employment, as this indicator accounts 
for company size. The calculation is made through the following coefficient $(z)$, which must be more than 1.

$$
z=\frac{\frac{\text { Employment in the } F \& B \text { industry in the territory }}{\text { Total employment in the territory }} y_{i}}{\frac{\text { Employment in the F\&B industry in Spain }}{\text { Total employment in Spain }}}>1
$$

\subsubsection{Control Variables}

INDUSTRIAL SECTOR (SECT). Finally, various studies in the field of industrial economy have demonstrated that company performance can be influenced by the sector [162]. Therefore, we have included a control variable of the industrial sector (SECT). This is a dichotomous variable that takes a value of 1 for food industry companies (section 10 of the Clasificación Nacional de Actividades Económicas, CNAE) and a value of 0 for beverage industry companies (section 11 of the CNAE).

\subsection{Analysis Technique}

The analysis technique used to test the three hypotheses is multiple regression analysis. Multiple regression is a powerful and robust statistical technique often used to test theories in various academic disciplines, including the field of companies [163]. Given the variability in the data and to facilitate the interpretation of the results, we have taken the variables of the logarithmic model. In this way, the coefficients measured through the regression technique can be directly interpreted as elasticities. This is a common practice in empirical data analysis [164].

The final multiple linear regression equation is as follows:

$$
\log \operatorname{ENTR}_{i}=\beta_{0}+\beta_{1} \log A G G L_{i}+\beta_{2} \log I N S T_{i}+\beta_{3} \log K N O W_{i}+\beta_{4} S E C T_{1}+\varepsilon_{i}
$$

where $i$ represents each cluster or industrial district in the sample, $\beta_{i}$ is the measured coefficient of the model, $\log (E N T R)$ represents the logarithm of the entrepreneurship variable, $\log (A G G L)$ is the logarithm of the agglomeration variable, $\log (I N S T)$ is the logarithm of the institutions variable, $\log (K N O W)$ is the logarithm of the knowledge variable, and (SECT) is the industrial sector control variable.

The regressions were conducted using the STATA software with standard robust errors to account for any heteroscedasticity in the sample. Compared with other software (e.g., SPSS), STATA has the advantage of allowing the calculation of robust standard errors when performing regressions. The regression method used was that of ordinary least squares (OLS).

\section{Results}

The results are presented in two parts. The first part shows the statistical results around the differences in the entrepreneurial capacities of the sample food industry clusters. The second part presents the results of the statistical analysis of the model used to test our hypotheses.

As mentioned earlier, we have analyzed 37 food and beverage clusters in Spain. We found a total of 185 newly created companies in Spanish food and beverage clusters from 2013 to 2017 . More concretely, there were 112 food companies (60.54\%) (CNAE 10) and 73 beverage companies (39.46\%) (CNAE 11).

In the first part, Figure 2 shows the percentage (and number) of newly created companies in each cluster from the total number of companies at the end of the period (see Appendix A). Three groups can be identified according to the new firm formation capacities in the cluster, each with different entrepreneurial evolution patterns. 


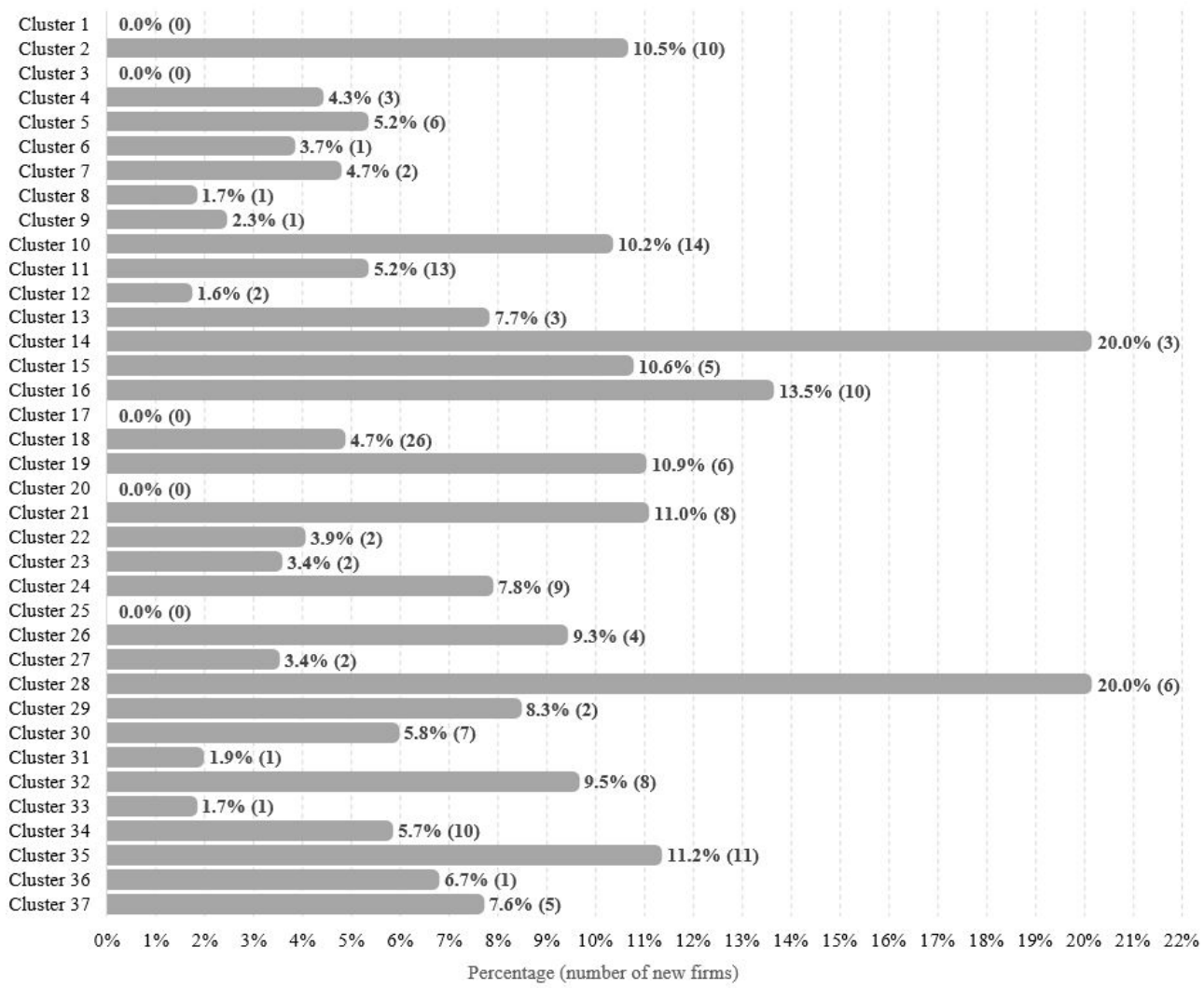

Figure 2. New firm formation in the 37 food and beverage clusters as a percentage of total companies in the cluster (2013-2017). Source: own work.

The first group includes clusters with a high rate of new firm formation, showing greater business dynamism, which makes them more vigorous and competitive. This group is made up of nine clusters, with two-digit percentages of new companies in the period. The second group is comprised of clusters with new firm formation percentage rates that are positive but below two digits. This group is made up of 23 clusters. Finally, the third group, with five clusters, includes clusters with a null new firm formation capacity.

The second part of the results examines the factors of entrepreneurship in the clusters, and we estimated the Equation (1) with the OLS method for 2013-2017. The results obtained from the multiple linear regression are shown in Table 1. The goodness of fit of the model is confirmed by the value of the coefficient of determination- 2 - and the highly significant $F$ statistic. The explanatory variables included in the regression explain $60.91 \%$ of the variability in new firm formation.

Table 1. Results of the multiple regression analysis.

\begin{tabular}{lcccccc}
\hline Log_ENTR & $\boldsymbol{\beta}$ & $\mathbf{t}$ & $\mathbf{P}>|\mathbf{t}|$ & Hypoth. & \multicolumn{2}{c}{ [95\% Conf. Interval] } \\
\hline Log_AGGL & $0.802^{* * *}$ & 13.85 & 0.000 & $\mathrm{H} 1$ & 0.688 & 0.916 \\
Log_INST & $0.448^{* *}$ & 2.91 & 0.004 & $\mathrm{H} 2$ & 0.145 & 0.751 \\
Log_KNOW & $-0.425^{*}$ & -2.70 & 0.008 & $\mathrm{H} 3$ & -0.735 & -0.114 \\
C & $0.231^{* *}$ & 2.97 & 0.003 & & 0.078 & 0.384 \\
SECT & $-5.744^{* * *}$ & -36.88 & 0.000 & & -6.052 & -5.437 \\
\hline
\end{tabular}

Note: ${ }^{*} p<0.1 ;{ }^{* *} p<0.05 ;{ }^{* * *} p<0.001$.

In the first step, we analyzed the possible existence of spatial autocorrelation among the model variables through the Durbin Watson statistics, finding evidence for its existence, as the values were far removed from 2, meaning that the use of OLS is not optimum for the regression [165]. We then 
applied the test [166], finding heteroscedasticity after rejecting the null hypothesis. These two aspects were corrected through the White correction [167].

We also analyzed the presence of multicollinearity among the regressors with tolerance factors and variance inflation factors (VIF), which guarantee that the "amount by which the variance of each regression coefficient increases in relation to a situation in which all the predictor variables are not correlated" [168]. We found that all the VIF values are below 5 .

From the analysis and validation of the model, we can see in Table 1 that the regressors are statistically significant at $5 \%$, except for the variable $\log I N S T$, which is statistically significant at $10 \%$.

These results support hypothesis 1 , which proposed a positive relationship between the agglomeration variable and the dependent variable - entrepreneurship-given that the coefficient is 0.802 and statistically significant. Hypothesis 2 , of the positive influence of the institutions variable on the dependent variable - entrepreneurship - is also confirmed, as the coefficient is 0.448 and statistically significant. However, the coefficient of the knowledge variable is negative and statistically significant at a confidence level of $90 \%$. This leads us to reject hypothesis 3, as the influence of the knowledge variable on entrepreneurship is negative $(-0.425)$.

\section{Conclusions}

The study objectives are to offer new knowledge around the explanatory factors of the entrepreneurial capacity of industrial clusters and to analyze the differences in entrepreneurial capacity in the different food and beverage clusters in Spain.

The analysis of entrepreneurial capacity in these business settings reveals significant differences among the clusters analyzed. Once again, this finding shows that, despite having some common characteristics, clusters and industrial districts are idiosyncratic and have different evolutionary patterns to each other. This is the case even when they share the same general geographical space (country) and economic activity (food and beverage industry).

The results of the statistical analysis confirm that, firstly, entrepreneurship (new firm formation) in food and beverage clusters is favored by the agglomeration of this industry. These results are compatible with previous empirical evidence about entrepreneurship and agglomeration. Reference [4], in their study of new firm formation in the Netherlands, confirmed that a higher regional share of employment in a sector is beneficial for the regional relative employment from new firm formation in the food and beverage sector. This implies that sectoral specialization is a self-enforcing process.

Secondly, institutional thickness favors entrepreneurship in food industry clusters. Specifically, a higher presence of technological centers, research institutes, vocational training centers, entrepreneurs' associations, and interprofessional organizations of the food and beverage industry encourages the creation of new firms through different forms of business support. In fact, according to Reference [169], the successful clusters or districts are increasingly associated with the presence of local networks, based on the market and socio-institutional relationships among cluster firms.

Finally, the results with regard to available knowledge (training supply) are the opposite of what we expected. Not only is it not possible to confirm a positive relationship between available knowledge in the territory and entrepreneurship, but the result is negative. This indicates that more available knowledge in the region reduces the degree of entrepreneurship. These results are in line with the work of previous researchers [4], who found that the traditional drivers of new firm formation, such as economic growth and agglomeration effects, have a much stronger effect on new firm formation compared to measures of the regional knowledge base.

One of the explanations put forward for this negative relationship is that entrepreneurship in itself does not necessarily need training. The motivations for an individual or group of individuals to start a new business venture are more often related to personal factors, such as individual motivation, the desire to excel, the need to take on new challenges, or the presence of greater opportunities within the family or community, etc. Conversely, it is likely that people with a higher level of knowledge of a certain industry (obtained through formal training) will put this knowledge at the service of already 
established companies. This would be the case for managers at various levels of decision-making (corporative, competitive, or functional) who develop their professional careers in professionalized companies, as well as for other figures who also need specific training, such as technicians, specialists, etc. In effect, the district itself often acts as a focus of attraction for specialist workers from other geographical areas who find new possibilities for their professional development there.

In summary, we can conclude that the presence of institutions and the agglomeration of companies in the same sector are factors that help explain the creation of new companies in food and beverage clusters. In other words, these factors can help explain the higher levels of entrepreneurship in these business contexts. However, not only can training supply not be considered as an explanatory factor for entrepreneurship in clusters, but according to our results it has a negative effect on the creation of new companies.

\subsection{Managerial Implications}

This paper contributes by incorporating evidence from the food and beverages clusters situated in Spain. There are some theoretical and practical implications that can be drawn from the study. At the theoretical level, we can highlight the link between theoretical approaches, such as strategic management, cluster, and industrial district theory and entrepreneurship. Furthermore, it is interesting to investigate the influence of different factors on entrepreneurship in a specific socioeconomic and institutional context, among which we can highlight local territorial agglomerations.

At the practical level, the study can help managers responsible for territorial development policies and for entrepreneurship training, in particular in orientating the development of specific governmental actions to foment regional entrepreneurship, as well as in raising consciousness around the importance of certain factors in the initial entrepreneurial decision. In fact, this work encourages companies to strengthen productive specialization as well as institutional thickness in the food and beverage districts in Spain.

Generally, not all clusters show the same levels of entrepreneurship, even when they are operating in relatively homogenous markets. Therefore, managers who want to start an entrepreneurial activity should select carefully where they locate their firm, since this can limit or increase their future development possibilities. In fact, managers usually look for locations within clusters, while governments have made significant investments in promoting them, for example accessing a range of existing European policies such as the Small Business Act, the Lisbon Agenda, and the European Research Area or the Europe 2020 strategy.

\subsection{Limitations and Future Research}

This study has a series of limitations that must be taken into account for future lines of research. First, the data are exclusively from the Spanish food industry, which means that the application of this analysis to other industries could lead to different results. In fact, we consider it very interesting to be able to compare the results obtained in the present work with other studies applied to contexts that are similar but different, such as different geographical areas or other industry clusters in Spain.

Second, it is evident that there are other factors, both environmental (for example, the entrepreneurial tradition of the region or specific governmental actions directed at incentivizing entrepreneurship) and company-related factors (for example, size, the ownership structure of new companies, or previous entrepreneurship experience), which are not included in the model and could provide information around the type of entrepreneurship found in each cluster. To overcome these limitations, we propose that future research analyzes the influence of some of these variables on entrepreneurship in clusters.

Author Contributions: Conceptualization, P.S.-L. and B.M.-L.; methodology, L.R.-F.; software, L.R.-F.; formal analysis, B.M.-L.; investigation, E.S.-G.; resources, E.C.-C.; data curation, P.S.-L.; writing-original draft preparation, E.S.-G.; writing-review and editing, P.S.-L.; visualization, B.M.-L.; supervision, E.C.-C.; project administration, P.S.-L. All authors have read and agreed to the published version of the manuscript. 
Funding: This research received no external funding.

Acknowledgments: We want to thank the anonymous reviewers for their valuable comments for the revised version of this paper.

Conflicts of Interest: The author declares no conflict of interest.

\section{Appendix A}

Table A1. Food and beverage Spanish cluster features.

\begin{tabular}{|c|c|c|c|c|c|c|}
\hline Cluster ID & Name & $\begin{array}{c}\text { Productive } \\
\text { Specialization }\end{array}$ & Province & $\begin{array}{c}\text { Cluster } \\
\text { Population }\end{array}$ & $\begin{array}{l}\text { Number } \\
\text { Firms }\end{array}$ & $\begin{array}{l}\text { New Firm } \\
\text { Formation }\end{array}$ \\
\hline Cluster 1 & Alhama de Murcia & Meat & Murcia & 53,230 & 47 & 0 \\
\hline Cluster 2 & Alzira & Various & Valencia & 178,398 & 95 & 10 \\
\hline Cluster 3 & Bedmar y Garcíez & $\begin{array}{l}\text { Fruits and } \\
\text { vegetables }\end{array}$ & Jaén & 4146 & 13 & 0 \\
\hline Cluster 4 & Calahorra & Various & La Rioja & 38,611 & 70 & 3 \\
\hline Cluster 5 & Cambados & Fish & Pontevedra & 24,423 & 115 & 6 \\
\hline Cluster 6 & Cariñena & Beverages & Zaragoza & 7567 & 27 & 1 \\
\hline Cluster 7 & Cenicero & Beverages & La Rioja & 3030 & 43 & 2 \\
\hline Cluster 8 & Estepa & Other f.p. & Sevilla & 19,999 & 59 & 1 \\
\hline Cluster 9 & Fregenal de la Sierra & Meat & Badajoz & 10,363 & 43 & 1 \\
\hline Cluster 10 & Girona & Meat & Girona & 200,119 & 137 & 14 \\
\hline Cluster 11 & Guijuelo & Meat & Salamanca & 14,999 & 249 & 13 \\
\hline Cluster 12 & Haro & Beverages & La Rioja & 18,884 & 125 & 2 \\
\hline Cluster 13 & Higuera la Real & Meat & Badajoz & 39,027 & 39 & 3 \\
\hline Cluster 14 & Jabugo & Meat & Huelva & 3983 & 15 & 3 \\
\hline Cluster 15 & Jijona & Other f.p. & Alicante & 9418 & 47 & 5 \\
\hline Cluster 16 & Jumilla & Beverages & Murcia & 25,362 & 74 & 10 \\
\hline Cluster 17 & La Roda de Andalucía & $\begin{array}{l}\text { Fruits and } \\
\text { vegetables }\end{array}$ & Sevilla & 4278 & 6 & 0 \\
\hline Cluster 18 & Logroño & Various & La Rioja & 211,709 & 549 & 26 \\
\hline Cluster 19 & Lorquí & $\begin{array}{l}\text { Fruits and } \\
\text { vegetables }\end{array}$ & Murcia & 37,937 & 55 & 6 \\
\hline Cluster 20 & Marcilla & $\begin{array}{l}\text { Fruits and } \\
\text { vegetables }\end{array}$ & Navarra & 6168 & 6 & 0 \\
\hline Cluster 21 & Molina de Segura & $\begin{array}{l}\text { Fruits and } \\
\text { vegetables }\end{array}$ & Murcia & 103,128 & 73 & 8 \\
\hline Cluster 22 & Mollerussa & Meat & Lleida & 36,738 & 51 & 2 \\
\hline Cluster 23 & Montilla & Various & Córdoba & 23,365 & 56 & 2 \\
\hline Cluster 24 & Olot & Meat & Girona & 52,010 & 116 & 9 \\
\hline Cluster 25 & Ólvega & Meat & Soria & 7660 & 26 & 0 \\
\hline Cluster 26 & Puente Genil & Other f.p. & Córdoba & 30,072 & 43 & 4 \\
\hline Cluster 27 & Requena & Beverages & Valencia & 22,353 & 59 & 2 \\
\hline Cluster 28 & Riudellots de la Selva & Meat & Girona & 28,929 & 30 & 6 \\
\hline Cluster 29 & Rute & Other f.p. & Córdoba & 13,818 & 24 & 2 \\
\hline Cluster 30 & Sant Sadurní dAnoia & Beverages & Barcelona & 54,098 & 120 & 7 \\
\hline Cluster 31 & Tarancón & Meat & Cuenca & 27,116 & 54 & 1 \\
\hline Cluster 32 & Torrijos & Meat & Toledo & 37,065 & 84 & 8 \\
\hline Cluster 33 & Valdepeñas & Beverages & Ciudad Real & 32,469 & 59 & 1 \\
\hline Cluster 34 & Vic & Meat & Barcelona & 138,009 & 175 & 10 \\
\hline Cluster 35 & Vilagarcía de Arousa & Fish & Pontevedra & 71,786 & 98 & 11 \\
\hline Cluster 36 & Villafranca & $\begin{array}{l}\text { Fruits and } \\
\text { vegetables }\end{array}$ & Navarra & 7329 & 15 & 1 \\
\hline Cluster 37 & Villarejo de Salvanés & Other f.p. & Madrid & 50,052 & 66 & 5 \\
\hline Total & & & & $1,647,648$ & 2963 & 185 \\
\hline
\end{tabular}

Note: Other f.p.: Other food products.

\section{References}

1. Hessels, J.; Naudé, W. The intersection of the fields of entrepreneurship and development economics: A review towards a new view. J. Econ. Surv. 2019, 33, 389-403. [CrossRef]

2. Haltiwanger, J.; Jarmin, R.S.; Miranda, J. Who creates jobs? Small versus large versus young. Rev. Econ. Stat. 2013, 95, 347-361. [CrossRef] 
3. Rijkers, B.; Laderchi, C.; Teal, F. Who Benefits from Promoting Small Enterprises? Some Empirical Evidence from Ethiopia. World Dev. 2010, 38, 523-540. [CrossRef]

4. Knoben, J.; Ponds, R.; Van Oort, F. Employment from new firm formation in the Netherlands: Agglomeration economies and the knowledge spillover theory of entrepreneurship. Entrep. Reg. Dev. 2011, 23, 135-157. [CrossRef]

5. Alvarez, C.; Urbano, D.; Coduras, A.; Ruiz-Navarro, J. Environmental conditions and entrepreneurial activity: A regional comparison in Spain. J. Small Bus. Enterp. Dev. 2011, 18, 120-140. [CrossRef]

6. Grant, R.M. Toward a knowledge-based theory of the firm. Strateg. Manag. J. 1996, 17, 109-122. [CrossRef]

7. Spender, J.C. Making knowledge the basis of a dynamic theory of the firm. Strateg. Manag. J. 1996, 17, 45-62. [CrossRef]

8. Zack, M.H. Developing a Knowledge Strategy. Calif. Manag. Rev. 1999, 41, 125-145. [CrossRef]

9. Bishop, P.; Brand, S. Human capital, diversity, and new firm formation. Serv. Ind. J. 2014, 34, 567-583. [CrossRef]

10. Davidsson, P.; Lindmark, L.; Olofsson, C. New firm formation and regional development in Sweden. Reg. Stud. 1994, 28, 395-410. [CrossRef]

11. Guesnier, B. Regional variations in new firm formation in France. Reg. Stud. 1994, 28, 347-358. [CrossRef]

12. Zhu, X.; Liu, Y.; He, M.; Luo, D.; Wu, Y. Entrepreneurship and industrial clusters: Evidence from China industrial census. Small Bus. Econ. Stud. 2019, 52, 595-616. [CrossRef]

13. Gartner, W.B. Some suggestions for research on entrepreneurial traits and characteristics. Entrep. Theory Pract. 1989, 14, 27-38. [CrossRef]

14. Hébert, R.; Link, A. The Entrepreneur: Mainstream Views and Radical Critiques, 2nd ed.; Praeger Publishers: New York, NY, USA, 1988.

15. Audretsch, D.B.; Keilbach, M.C.; Lehmann, E.E. Entrepreneurship and Economic Growth, 1st ed.; Oxford University Press: New York, NY, USA, 2006.

16. Reynolds, P.; Storey, D.J.; Westhead, P. Explaining regional variation in business births and deaths: US $1976-88$. Small Bus. Econ.Stud. 1995, 7, 389-407. [CrossRef]

17. Wennberg, K.; Lindqvist, G. The effect of clusters on the survival and performance of new firms. Small Bus. Econ. Stud. 2010, 34, 221-241. [CrossRef]

18. Long, C.; Zhang, X. Cluster-based industrialization in China: Financing and performance. J. Int. Econ. Stud. 2011, 84, 112-123. [CrossRef]

19. Long, C.; Zhang, X. Patterns of China's industrialization: Concentration, specialization, and clustering. China Econ. Rev. 2012, 23, 593-612. [CrossRef]

20. Fleisher, B.; Hu, D.; McGuire, W.; Zhang, X. The evolution of an industrial cluster in China. China Econ. Rev. 2010, 21, 456-469. [CrossRef]

21. Krugman, P.R. Geography and Trade, 1st ed.; The MIT Press: Cambridge, MA, USA, 1991.

22. Marshall, A. Principles of Economics, 1st ed.; Macmillan: London, UK, 1920.

23. Storper, M. The Regional World: Territorial Development in A Global Economy, 1st ed.; The Guilford Press: New York, NY, USA, 1997.

24. Feldman, M.P.; Francis, J.; Bercovitz, J. Creating a cluster while building a firm: Entrepreneurs and the formation of industrial clusters. Reg. Stud. 2005, 39, 129-141. [CrossRef]

25. Claver-Cortés, E.; Marco-Lajara, B.; Seva-Larrosa, P.; Ruiz-Fernández, L. Competitive advantage and industrial district: A review of the empirical evidence about the district effect. Compet. Rev. 2019, 29, $211-235$. [CrossRef]

26. Rocha, H.O. Entrepreneurship and development: The role of clusters. Small Bus. Econ.Stud. 2004, 23, 363-400. [CrossRef]

27. Rocha, H.O.; Sternberg, R. Entrepreneurship: The role of clusters theoretical perspectives and empirical evidence from Germany. Small Bus. Econ. 2005, 24, 267-292. [CrossRef]

28. Ministerio de Agricultura, Pesca y Alimentación. Agricultura, Pesca y Alimentación en España 2018. Memoria Annual; Ministerio de Agricultura, Pesca y Alimentación: Madrid, Spain, 2018. Available online: https: //bit.ly/38wqBxu (accessed on 30 June 2020).

29. Miguel, G.; Puig, F.; Urzelai, B. Agglomerations, Clusters and Industrial Districts: Evolution and Opportunities for future research. In Econmics Clusters and Globalization: Diversity and Resilience, 1st ed.; Puig, F., Urzelai, B., Eds.; Routledge: Abingdon, UK, 2019. 
30. Kukalis, S. Agglomeration economies and firm performance: The case of industry clusters. J. Manag. 2010, 36, 453-481. [CrossRef]

31. Beaudry, C.; Swann, P. Growth in industrial clusters: A bird's eye view of the United Kingdom. Discussion. Stanf. Inst. Econ. Policy Res. 2001.

32. Shane, S.; Venkataraman, S. The promise of entrepreneurship as a field of research. Acad. Manag. Rev. 2000, 25, 217-226. [CrossRef]

33. Autio, E.; Kenney, M.; Mustar, P.; Siegel, D.; Wright, M. Entrepreneurial innovation: The importance of context. Res. Policy 2014, 43, 1097-1108. [CrossRef]

34. Malecki, E. Technology and Economic Development: The Dynamics of Local, Regional, and National Change, 1st ed.; Longman Scientific \& Technical: New York, NY, USA, 1991.

35. Wagner, J.; Sternberg, R. Start-up activities, individual characteristics, and the regional milieu: Lessons for entrepreneurship support policies from German micro data. Ann. Reg. Sci. 2004, 38, 219-240. [CrossRef]

36. Bosma, N.; Van Stel, A.; Suddle, K. The geography of new firm formation: Evidence from independent start-ups and new subsidiaries in the Netherlands. Int. Entrep. Manag. J. 2008, 4, 129-146. [CrossRef]

37. Koo, J.; Cho, K.R. New firm formation and industry clusters: A case of the drugs industry in the US. Growth Chang. 2011, 42, 179-199. [CrossRef]

38. Acs, Z.J.; Stam, E.; Audretsch, D.B.; O'Connor, A. The lineages of the entrepreneurial ecosystem approach. Small Bus. Econ. Stud. 2017, 49, 1-10. [CrossRef]

39. Armington, C.; Acs, Z.J. The determinants of regional variation in new firm formation. Reg. Stud. 2002, 36, 33-45. [CrossRef]

40. Garofoli, G. New firm formation and regional development: The Italian case. Reg. Stud. 1994, 28, 381-393. [CrossRef]

41. Romero-Martínez, A.M.; Montoro-Sánchez, Á. How clusters can encourage entrepreneurship and venture creation. Reasons and advantages. Int. Entrep. Manag. J. 2008, 4, 315-329. [CrossRef]

42. Shane, S. Prior Knowledge and the Discovery of Entrepreneurial Opportunities. Organ. Sci. 2000, 11, 448-469. [CrossRef]

43. Audretsch, D.B.; Fritsch, M. The geography of firm births in Germany. Reg. Stud. 1994, 28, 359-365. [CrossRef]

44. Johansen, F.R.; Kerndrup, S.; Andersson, G.; Rubach, S. A view of clustering as emergent and innovative processes. Ind. Innov. 2020, 27, 390-419. [CrossRef]

45. Marco-Lajara, B.; Zaragoza-Sáez P del, C.; Claver-Cortés, E.; Úbeda-García, M. Hotel performance and knowledge sources in Spanish tourism districts. Curr. Issues Tour. 2018, 21, 1988-2013. [CrossRef]

46. Becattini, G. The Marshallian industrial district as a socioeconomic notion. In Industrial Districts and Inter-Firm Co-Operation in Italy, 1st ed.; Pyke, F., Becattini, G., Sengenberger, W., Eds.; International Institute for Labour Studies: Geneva, Switzerland, 1990; Volume 1, pp. 37-51.

47. Garud, R.; Karnøe, P. Path creation as a process of mindful deviation. In Path Dependence and Creation, 1st ed.; Garud, R., Karnøe, P., Eds.; Lawrence Erlbaum Associates Publishers: Mahwah, NJ, USA, 2001; Volume 1, pp. 1-38.

48. Tsvetkova, A.; Partridge, M. Knowledge-based service economy and firm entry: An alternative to the knowledge spillover theory of entrepreneurship. Small Bus. Econ. 2019, 0, 1-21. [CrossRef]

49. Acs, Z.J.; Braunerhjelm, P.; Audretsch, D.B.; Carlsson, B. The knowledge spillover theory of entrepreneurship. Small Bus. Econ. Stud. 2009, 32, 15-30. [CrossRef]

50. Hervas-Oliver, J.L.; Lleo, M.; Cervello, R. The dynamics of cluster entrepreneurship: Knowledge legacy from parents or agglomeration effects? The case of the Castellon ceramic tile district. Res. Policy 2017, 46, 73-92. [CrossRef]

51. Agarwal, R.; Audretsch, D.; Sarkar, M.B. Knowledge spillovers and strategic entrepreneurship. Strateg. Entrep. J. 2010, 4, 271-283. [CrossRef]

52. Muscio, A. Patterns of innovation in industrial districts: An empirical analysis. Ind. Innov. 2006, 13, $291-312$. [CrossRef]

53. Saba, A. El Modelo Italiano: La Especialización Flexible y Los Distritos Industriales, 1st ed.; Editorial de la Universidad Nacional de La Plata: La Plata, Argentina, 1997.

54. Renski, H. External economies of localization, urbanization and industrial diversity and new firm survival. Pap. Reg. Sci. 2011, 90, 473-502. [CrossRef] 
55. Porter, M.E. Competitive Advantage of Nations: Creating and Sustaining Superior Performance, 1st ed.; The Free Press: New York, NY, USA, 2011.

56. Delgado, M.; Porter, M.E.; Stern, S. Clusters and entrepreneurship. J. Econ. Geogr. 2010, 10, 495-518. [CrossRef]

57. Brasili, C.; Famfani, R. Agri-food districts: Theory and evidence. In The New European Rurality: Strategies for Small Firms, 1st ed.; Noronha Vaz, T., Morgan, E.J., Nijkamp, P., Eds.; MPG Books, Ltd.: Cornwall, UK, 2006; Volume 1, pp. 61-86.

58. Giuliani, E.; Pietrobelli, C.; Rabellotti, R. Upgrading in global value chains: Lessons from latin American clusters. World Dev. 2005, 33, 549-573. [CrossRef]

59. Sforzi, F. Local development in the experience of Italian industrial districts. In From Industrial Districts to Local Development: An Itinerary of Research, 1st ed.; Becattini, G., Bellandi, M., Dei Ottati, G., Sforzi, F., Eds.; Edward Elgar Publishing: Cheltenham, UK, 2003; Volume 1, pp. 157-183.

60. McCann, B.T.; Folta, T.B. Location matters: Where we have been and where we might go in agglomeration research. J. Manag. 2008, 34, 532-565. [CrossRef]

61. Dei Ottati, G. El efecto distrito: Algunos aspectos conceptuales de sus ventajas competitivas. Econ. Ind. 2006, 359, 73-80.

62. Glaeser, E.L.; Kerr, W.R. Local industrial conditions and entrepreneurship: How much of the spatial distribution can we explain? J. Econ. Stud. Manag. Strategy 2009, 18, 623-663. [CrossRef]

63. Li, P.; Bathelt, H. Location strategy in cluster networks. J. Int. Bus. Stud. 2018, 49, 967-989. [CrossRef]

64. Maskell, P. Towards a Knowledge-based Theory of the Geographical Cluster. Ind. Corp. Chang. 2001, 10, 921-943. [CrossRef]

65. Li, P.F. Horizontal versus vertical learning: Divergence and diversification of lead firms in the Hangji toothbrush cluster, China. Reg. Stud. 2014, 48, 1227-1241. [CrossRef]

66. DiMaggio, P.J.; Powell, W.W. The iron cage revisited: Institutional isomorphism and collective rationality in organizational fields. Am. Sociol. Rev. 1983, 1, 147-160. [CrossRef]

67. Daft, R.L.; Lengel, R.H. Organizational information requirements, media richness and structural design. Manag. Sci. 1986, 32, 554-571. [CrossRef]

68. Jaffe, A.B.; Trajtenberg, M.; Henderson, R. Geographic localization of knowledge spillovers as evidenced by patent citations. Q. J. Econ. Stud. 1993, 108, 577-598. [CrossRef]

69. Storper, M.; Venables, A.J. Buzz: Face-to-face contact and the urban economy. J. Econ. Geogr. 2004, 4, 351-370. [CrossRef]

70. Morrison, A.; Rabellotti, R. Knowledge and information networks in an Italian wine cluster. Eur. Plan. Stud. 2009, 17, 983-1006. [CrossRef]

71. Brenner, T.; Greif, S. The dependence of innovativeness on the local firm population-An empirical study of German patents. Ind. Innov. 2006, 13, 21-39. [CrossRef]

72. Gambardella, A.; Giarratana, M.S. Organizational attributes and the distribution of rewards in a region: Managerial firms vs. knowledge clusters. Organ. Sci. 2010, 21, 573-586. [CrossRef]

73. Malecki, E. Regional social capital: Why it matters. Reg. Stud. 2012, 46, 1023-1039. [CrossRef]

74. Molina-Morales, F.X.; Martínez-Fernández, M.T. Social networks: Effects of social capital on firm innovation. J. Small Bus. Manag. 2010, 48, 258-279. [CrossRef]

75. Molina-Morales, F.X.; Martínez-Fernández, M.T. Too much love in the neighborhood can hurt: How an excess of intensity and trust in relationships may produce negative effects on firms. Strateg. Manag. J. 2009, 30, 1013-1023. [CrossRef]

76. Saxenian, A. Inside-out: Regional networks and industrial adaptation in Silicon Valley and Route 128. Cityscape 1996, 2, 41-60.

77. Audretsch, B. Agglomeration and the location of innovative activity. Oxf. Rev. Econ. Policy 1998, 14, 18-29. [CrossRef]

78. Bathelt, H.; Malmberg, A.; Maskell, P. Clusters and knowledge: Local buzz, global pipelines and the process of knowledge creation. Prog. Hum. Geogr. 2004, 28, 31-56. [CrossRef]

79. Isaksen, A.; Jakobsen, S.E.; Njøs, R.; Normann, R. Regional industrial restructuring resulting from individual and system agency. Innov. Eur. J. Soc. Sci. Res. 2019, 32, 48-65. [CrossRef]

80. MacKinnon, D.; Dawley, S.; Pike, A.; Cumbers, A. Rethinking path creation: A geographical political economy approach. Econ. Geogr. 2019, 95, 113-135. [CrossRef] 
81. Graven, M.; Lerman, S.; Wenger, E. Communities of practice: Learning, meaning and identity. J. Math. Teach. Educ. 1998, 6, 185-194. [CrossRef]

82. Lorenzen, M.; Maskell, P. The cluster as a nexus of knowledge creation. In Regional Economies as Knowledge Laboratories, 1st ed.; Cooke, P., Piccaluga, A., Eds.; Edward Elgar Publishing: Cheltenham, UK, 2005; Volume 1, pp. 77-92.

83. Bronzini, R. FDI Inflows, agglomeration and host country firms' size: Evidence from Italy. Reg. Stud. 2007, 41, 963-978. [CrossRef]

84. McCann, P.; Mudambi, R. The location behavior of the multinational enterprise: Some analytical issues. Growth Chang. 2004, 35, 491-524. [CrossRef]

85. Mudambi, R. Location, control and innovation in knowledge-intensive industries. J. Econ. Geogr. 2008, 8, 699-725. [CrossRef]

86. Porter, M.E. The role of location in competition. J. Econ. Stud. Bus. 1994, 1, 35-40. [CrossRef]

87. Porter, M.E. Location, competition, and economic development: Local clusters in a global economy. Econ. Dev. Q. 2000, 14, 15-34. [CrossRef]

88. Arthur, W.B. 'Silicon Valley' locational clusters: When do increasing returns imply monopoly? Math. Soc. Sci. 1990, 19, 235-251. [CrossRef]

89. McCann, B.T.; Folta, T.B. Performance differentials within geographic clusters. J. Bus. Ventur. 2011, 26, 104-123. [CrossRef]

90. Wang, L.; Madhok, A.; Xiao Li, S. Agglomeration and clustering over the industry life cycle: Toward a dynamic model of geographic concentration. Strateg. Manag. J. 2014, 35, 995-1012. [CrossRef]

91. Stam, E. Why butterflies don't leave: Locational behavior of entrepreneurial firms. Econ. Geogr. 2007, 83, 27-50. [CrossRef]

92. Du, J.; Lu, Y.; Tao, Z. Economic institutions and FDI location choice: Evidence from US multinationals in China. J. Comp. Econ. Stud. 2008, 36, 412-429. [CrossRef]

93. Branstetter, L. Is foreign direct investment a channel of knowledge spillovers? Evidence from Japan's FDI in the United States. J. Int. Econ. Stud. 2006, 68, 325-344. [CrossRef]

94. Cantwell, J.A.; Mudambi, R. Physical attraction and the geography of knowledge sourcing in multinational enterprises. Glob. Strat J. 2011, 1, 206-232. [CrossRef]

95. Diez-Vial, I. Geographical cluster and performance: The case of Iberian ham. Food Policy 2011, 36, 517-525. [CrossRef]

96. Frank, S.D.; Henderson, D.R. Transaction costs as determinants of vertical coordination in the U.S. Food Industries. Am. J. Agric. Econ. Stud 1992, 74, 941-950. [CrossRef]

97. Claver-Cortés, E.; Marco-Lajara, B.; Manresa-Marhuenda, E. Innovation in foreign enterprises: The influence exerted by location and absorptive capacity. Technol. Anal. Strateg. Manag. 2020, 1, 1-19. [CrossRef]

98. Nelson, R.R.; Winter, S.G. An Evolutionary Theory of Econ. Change, 1st ed.; Harvard University Press: Cambridge, MA, USA, 1982.

99. Saxenian, A. Regional Advantage, 1st ed.; Harvard University Press: Cambridge, MA, USA, 1996.

100. Li, X.; Zhang, Y.F.; Sun, L. Industry agglomeration, sub-national institutions and the profitability of foreign subsidiaries. Manag. Int. Rev. 2018, 58, 969-993. [CrossRef]

101. McEvily, B.; Zaheer, A. Bridging ties: A source of firm heterogeneity in competitive capabilities. Strateg. Manag. J. 1999, 20, 1133-1156. [CrossRef]

102. Baum, J.A.; Calabrese, T.; Silverman, B.S. Don't go it alone: Alliance network composition and startups' performance in Canadian biotechnology. Strateg. Manag. J. 2000, 21, 267-294. [CrossRef]

103. Belussi, F.; Sedita, S.R. Life cycle vs. multiple path dependency in industrial districts. Eur. Plan. Stud. 2009, 17, 505-528. [CrossRef]

104. Zucchella, A. Local cluster dynamics: Trajectories of mature industrial districts between decline and multiple embeddedness. J. Inst. Econ. Stud. 2006, 2, 21-44. [CrossRef]

105. Porter, M. Clusters and the new economics of competition in press. Harv. Bus. Rev. 1998, 76, 77-90.

106. Bertolini, P.; Govannetti, E. The internationalisation of an agri-food cluster: A case study. In Proceedings of the the Conference on Clusters, Industrial Districts and Firms: The Challenge of Globalization, Modena, Italy, 12-13 September 2003.

107. Padilla-Pérez, R. A regional approach to study technology transfer through foreign direct investment: The electronics industry in two Mexican regions. Res. Policy 2008, 37, 849-860. [CrossRef] 
108. Baumol, W.J. Entrepreneurship, Management, and the Structure of Payoffs, 1st ed.; MIT Press: London, UK, 1993.

109. Manolova, T.S.; Eunni, R.V.; Gyoshev, B.S. Institutional environments for entrepreneurship: Evidence from emerging economies in Eastern Europe. Entrep. Theory Pract. 2008, 32, 203-218. [CrossRef]

110. Li, T. Engagement in international entrepreneurship: Interactive effects of resource-based factors and institutional environments. J. Glob. Entrep. Res. 2019, 9, 1-17. [CrossRef]

111. Glaeser, E.L.; Kerr, W.R.; Ponzetto, G.A. Clusters of entrepreneurship. J. Urban Econ. Stud. 2010, 67, 150-168. [CrossRef]

112. Andersson, M.; Larsson, J.P. Local entrepreneurship clusters in cities. J. Econ. Geogr. 2016, 16, 39-66. [CrossRef]

113. Sunny, S.A.; Shu, C. Investments, incentives, and innovation: Geographical clustering dynamics as drivers of sustainable entrepreneurship. Small Bus. Econ. Stud. 2019, 52, 905-927. [CrossRef]

114. Torre, A.; Rallet, A. Proximity and localization. Reg. Stud. 2005, 39, 47-59. [CrossRef]

115. Holmes, R.M., Jr.; Miller, T.; Hitt, M.A.; Salmador, M.P. The interrelationships among informal institutions, formal institutions, and inward foreign direct investment. J. Manag. 2013, 39, 531-566. [CrossRef]

116. Myles Shaver, J.; Flyer, F. Agglomeration economies, firm heterogeneity, and foreign direct investment in the United States. Strateg. Manag. J. 2000, 21, 1175-1193. [CrossRef]

117. Hwang, H.; Powell, W.W. Institutions and entrepreneurship. In Handbook of Entrepreneurship Research, 1st ed.; Acs, J.Z., Audretsch, B.D., Eds.; Springer: Boston, MA, USA, 2005; Volume 1, pp. 201-232.

118. Estrin, S.; Korosteleva, J.; Mickiewicz, T. Which institutions encourage entrepreneurial growth aspirations? J. Bus. Ventur. 2013, 28, 564-580. [CrossRef]

119. Kreiser, P.M.; Marino, L.D.; Dickson, P.; Weaver, K.M. Cultural influences on entrepreneurial orientation: The impact of national culture on risk taking and proactiveness in SMEs. Entrep. Theory Pract. 2010, 34, 959-984. [CrossRef]

120. Raco, M. Assessing 'institutional thickness' in the local context: A comparison of Cardiff and Sheffield. Environ. Plan. A 1998, 30, 975-996. [CrossRef]

121. Keeble, D.; Lawson, C.; Moore, B.; Wilkinson, F. Collective learning processes, networking and 'institutional thickness' in the Cambridge region. Reg. Stud. 1999, 33, 319-332. [CrossRef]

122. Coulson, A.; Ferrario, C. 'Institutional thickness': Local governance and economic development in Birmingham, England. Int. J. Urban Reg. Res. 2007, 31, 591-615. [CrossRef]

123. Amin, A.; Thrift, N. Globalisation, institutional 'thickness' and the local economy. In Managing Cities: The New Urban Context. The New Urban Context, 1st ed.; Healey, P., Cameron, S., Davoudi, S., Graham, S., Madani-Pour, A., Eds.; John Wiley \& Sons: Chichester, UK, 1995; Volume 1, pp. 91-108.

124. Boucher, G.; Conway, C.; Van Der Meer, E. Tiers of engagement by universities in their region's development. Reg. Stud. 2003, 37, 887-897. [CrossRef]

125. Belzunegui Eraso, Á.; Miralles Amorós, M.Á.; Pastor Gosálbez, M.T. The role of institutional and territorial factors in innovation: The case of the spanish footwear components industry. J. Reg. Res. 2017, 39, 59-80.

126. Porter, M.E.; Ketels, C. Clusters and industrial districts: Common roots, different perspectives. In A Handbook of Industrial Districts, 1st ed.; Becattini, G., Bellandi, M., De Propis, L., Eds.; Edward Elgar Publishing: Cheltenham, UK, 2009; Volume 1, pp. 172-183.

127. Parra-Requena, G.; Ruiz-Ortega, M.J.; García-Villaverde, P.M. Social capital and effective innovation in industrial districts: Dual effect of absorptive capacity. Ind. Innov. 2013, 20, 157-179. [CrossRef]

128. Aghion, P.; Howitt, P. A model of growth through creative destruction. Econometrica 1990, 60, $323-352$. [CrossRef]

129. Grossman, G.M.; Helpman, E. Innovation and Growth in the Global Economy, 1st ed.; MIT Press: Cambridge, MA, USA, 1991.

130. Romer, P. Increasing returns and long-run growth. J. Political Econ. 1986, 94, 1002-1037. [CrossRef]

131. Romer, P. Are nonconvexities important for understanding growth? Am. Econ. Rev. 1990, 80, 97-103. [CrossRef]

132. Polanyi, M. The Tacit Dimension, 1st ed.; Routledge Kegan Paul: London, UK, 1966.

133. Audretsch, D.B.; Keilbach, M. The theory of knowledge spillover entrepreneurship. J. Manag. Stud. 2007, 44, 1242-1254. [CrossRef]

134. Tallman, S.; Jenkins, M.; Henry, N.; Pinch, S. Knowledge, clusters, and competitive advantage. Acad. Manag. Rev. 2004, 29, 258-271. [CrossRef] 
135. Anselin, L.; Varga, A.; Acs, Z. Local geographic spillovers between university research and high technology innovations. J. Urban Econ. Stud. 1997, 42, 422-448. [CrossRef]

136. Anselin, L.; Varga, A.; Acs, Z. Geographical spillovers and university research: A spatial econometric perspective. Growth Chang. 2000, 31, 501-515. [CrossRef]

137. Audretsch, D.B.; Feldman, M.P. R\&D spillovers and the geography of innovation and production. Am. Econ. Rev. 1996, 86, 630-640.

138. Keller, W. Geographic localization of international technology diffusion. Am. Econ. Rev. 2002, 92, $120-142$. [CrossRef]

139. Bae, J.; Koo, J. The nature of local knowledge and new firm formation. Ind. Corp. Chang. 2009, 18, 473-496. [CrossRef]

140. Juhász, S.; Lengyel, B. Creation and persistence of ties in cluster knowledge networks. J. Econ. Geogr. 2018, 18, 1203-1226. [CrossRef]

141. Amin, A. Industrial districts. In A Companion to Economic Geography, 1st ed.; Sheppard, E., Barnes, T.J., Eds.; Blackwell Publishers Ltd.: Oxford, UK, 2000; Volume 1, pp. 149-168.

142. Delgado, M.; Porter, M.E.; Stern, S. Clusters, convergence, and economic performance. Res. Policy 2014, 43, 1785-1799. [CrossRef]

143. Díaz-Díaz, N.L.; de Saá Pérez, P. The interaction between external and internal knowledge sources: An open innovation view. J. Knowl. Manag. 2014, 18, 430-446. [CrossRef]

144. Lucas, R.E. On the mechanics of economic development. J. Monet. Econ. Stud. 1988, 22, 3-42. [CrossRef]

145. Ranstad Research. El Futuro del Empleo en el Sector de la Industria Alimentaria. Available online: https://bit.ly/3e0LDW3 (accessed on 30 June 2020).

146. Whittington, K.B.; Owen-Smith, J.; Powell, W.W. Networks, Propinquity, and Innovation in Knowledge-intensive Industries. Adm. Sci. Q. 2009, 54, 90-122. [CrossRef]

147. Knudsen, M.P. The relative importance of interfirm relationships and knowledge transfer for new product development success. J. Prod. Innov. Manag. 2007, 24, 117-138. [CrossRef]

148. Tödtling, F.; Lehner, P.; Kaufmann, A. Do different types of innovation rely on specific kinds of knowledge interactions? Technovation 2009, 29, 59-71. [CrossRef]

149. Toner, P.; Marceau, J.; Hall, R.; Considine, G. Innovation agents: Vocational education and training skills in the present and future Australian innovation system. In Vocational Education and Training and Innovation: Research Readings, 1st ed.; Dawe, S., Ed.; NCVER: Adelaide, Australia, 2004; Volume 1, pp. 84-117.

150. Razak, A.A.; Saad, M. The role of universities in the evolution of the Triple Helix culture of innovation network: The case of Malaysia. Int. J. Technol. Manag. Sustain. Dev. 2007, 6, 211-225. [CrossRef]

151. Drejer, I.; Jørgensen, B.H. The dynamic creation of knowledge: Analysing public-private collaborations. Technovation 2005, 25, 83-94. [CrossRef]

152. Maggioni, M.A.; Uberti, T.E. Knowledge networks across Europe: Which distance matters? Ann. Reg. Sci. 2009, 43, 691-720. [CrossRef]

153. Kirchhoff, B.A.; Newbert, S.L.; Hasan, I.; Armington, C. The influence of university R \& D expenditures on new business formations and employment growth. Entrep. Theory Pract. 2007, 31, 543-559. [CrossRef]

154. Breschi, S.; Malerba, F. The geography of innovation and economic clustering: Some introductory notes. Ind. Corp. Chang. 2001, 10, 817-833. [CrossRef]

155. Bresnahan, T.; Gambardella, A.; Saxenian, A. "Old economy" inputs for "new economy" outcomes: Cluster formation in the new Silicon Valleys. Ind. Corp. Chang. 2001, 10, 835-860. [CrossRef]

156. Instituto Nacional de Estadística. Available online: https://afly.co/h313 (accessed on 27 May 2020).

157. Boix, R.; y Galletto, V. El nuevo mapa de los distritos industriales de España y su comparación con Italia y el Reino Unido (No. 06.04). Working Paper; Department of Applied Economics at Universitat Autonoma of Barcelona: Barcelona, Spain, 2006.

158. Sforzi, F. The empirical evidence of industrial districts in Italy. In A Handbook of Industrial Districts, 1st ed.; Becattini, G., Bellandi, M., De Propis, L., Eds.; Edward Elgar Publishing: Cheltenham, UK, 2009; Volume 1, pp. 327-342.

159. De Propris, L. The empirical evidence of industrial districts in Great Britain. In A Handbook of Industrial Districts, 1st ed.; Becattini, G., Bellandi, M., De Propris, L., Eds.; Edward Elgar Publishing: Cheltenham, UK, 2009; Volume 1, pp. 360-380. 
160. Marco-Lajara, B.; Claver-Cortés, E.; Úbeda-García, M.; Zaragoza-Sáez, P.D.C. Hotel performance and agglomeration of tourist districts. Reg. Stud. 2016, 50, 1016-1035. [CrossRef]

161. Boix, R.; Trullén, J. Industrial districts, innovation and I-district effect: Territory or industrial specialization? Eur. Plan. Stud. 2010, 18, 1707-1729. [CrossRef]

162. Bain, J.S. Industrial Organization; Wiley: New York, NY, USA, 1968.

163. Scandura, T.A.; Williams, E.A. Research methodology in management: Current practices, trends, and implications for future research. Acad. Manag. J. 2000, 43, 1248-1264. [CrossRef]

164. Gujarati, D.N. Basic Econometrics, 1st ed.; Tata McGraw-Hill Education: New Delhi, India, 2009.

165. Cliff, A.; Ord, K. Testing for spatial autocorrelation among regression residuals. Geogr. Anal. 1972, 4, $267-284$. [CrossRef]

166. Breusch, T.S.; Pagan, A.R. A simple test for heteroscedasticity and random coefficient variation. J. Econ. Soc. 1979, 47, 1287-1294. [CrossRef]

167. Wooldridge, J.M. Econometric Analysis of Cross Section and Panel Data, 2nd ed.; The MIT Press: Cambridge, MA, USA, 2010.

168. Cohen, P.; West, S.G.; Aiken, L.S. Applied Multiple Regression/Correlation Analysis for the Behavioral Sciences, 2nd ed.; Psychology Press: New York, NY, USA, 2014.

169. Giuliani, E. The selective nature of knowledge networks in clusters evidence from the wine industry. J. Econ. Geogr. 2007, 7, 139-168. [CrossRef]

(C) 2020 by the authors. Licensee MDPI, Basel, Switzerland. This article is an open access article distributed under the terms and conditions of the Creative Commons Attribution (CC BY) license (http://creativecommons.org/licenses/by/4.0/). 